\title{
Social Capital and Economic Growth: Empirical Evidence From OIC Countries
}

\author{
Hantoro Ksaid Notolegowo' \& Samsubar Saleh ${ }^{2}$
}

\begin{abstract}
This research investigates the effect of constructive social capital such as religious tolerance, political participation, and marriage; and destructive social capital such as the corruption culture and discrimination behavior towards the economic growth rate of member countries of the Islamic Cooperation Organization (OIC) 2014-2017. The results of the research estimation using the technique of fixed effect (FE) from the panel data of the OIC countries show that religious tolerance measured using the freedom of religion index (FRI) shows a positive and significant effect on the economic growth rate; political participation as measured by political rights index (PRI) has a significant negative effect on the economic growth rate; marriage measured using the percentage of married woman (PMW) has a positive effect on the economic growth rate but is not significant; corruption culture measured using corruption perception index (CPI) has a negative and not significant effect on the economic growth rate; and discrimination behavior measured using discrimination and violence against minorities index (DVI) shows a negative and not significant effect on the economic growth rate.
\end{abstract}

Keywords: Social Capital, Constructive, Destructive, Economic Growth, OIC

\begin{abstract}
Abstrak. Penelitian ini menginvestigasi pengaruh modal sosial konstruktif (constructive social capital) seperti toleransi beragama, partisipasi politik, dan pernikahan, serta modal sosial destruktif (destructive social capital) seperti budaya korupsi dan perilaku diskriminasi terhadap tingkat pertumbuhan ekonomi negaranegara anggota Organisasi Kerjasama Islam (OKI) 2014-2017. Hasil estimasi penelitian menggunakan teknik analisis fixed effect (FE) dari data panel negara-negara OKI menunjukkan bahwa toleransi beragama yang diukur menggunakan freedom of religion index (FRI) menunjukkan pengaruh positif dan signifikan terhadap tingkat pertumbuhan ekonomi; partisipasi politik yang diukur menggunakan political rights index (PRI) memberikan pengaruh negatif signifikan terhadap tingkat pertumbuhan ekonomi; pernikahan yang diukur menggunakan percentage of married woman (PMW) memiliki pengaruh positif terhadap tingkat pertumbuhan ekonomi namun tidak signifikan; budaya korupsi yang diukur menggunakan corruption perception index (CPI) memberikan pengaruh negatif dan tidak signifikan terhadap tingkat perumbuhan ekonomi; dan perilaku diskriminasi yang diukur menggunakan discrimination and violence against minorities index (DVI) menunjukkan pengaruh negatif dan tidak signifikan terhadap tingkat pertumbuhan ekonomi.
\end{abstract}

Kata kunci: Modal Sosial, Konstruktif, Destruktif, Pertumbuhan Ekonomi, OKI

\footnotetext{
${ }^{1,2}$ Department of Islamic Economics, Gadjah Mada University, Sleman, Yogyakarta, 55281, Indonesia

E-mail: ${ }^{1}$ hantoroksaid@gmail.com, ${ }^{2}$ ssamsubar@yahoo.com
} 


\section{Introduction}

The Islamic Cooperation Organization (OIC) was established as an effort to discuss and at the same time, find solutions to a number of issues and problems that occur in Islamic countries. Initially the organization was established as a response to the burning of the Al-Aqsa Mosque by Zionists in August 1969 and aimed at mobilizing the unity of Muslim countries. But then the OIC charter was adopted on February 27, 1970 to strengthen cooperation in the political, economic, social, cultural and scientific fields and support for all Muslims to maintain dignity, independence and national rights.

At present, there are concerns in terms of the welfare of the people in OIC countries due to economic instability caused by the social crisis. The social crisis includes civil wars and terrorism (Sab, 2014); political instability (Uddin \& Masih, 2016); low quality of human resources (UNDP, 2016); corruption culture (Ertimi, Dowa, Albisht, \& Oqab, 2016); and discrimination (SESRIC, 2016). Based on data published by the World Bank in 2017, it shows that OIC countries affected by the social crisis tend to have low growth rates, as shown in Table 1 . This phenomenon indicates a close link between economic performance and social conditions.

Table 1. Economic Growth and Social Crisis in OIC Countries

\begin{tabular}{cccl}
\hline No. & Country & $\begin{array}{c}\text { Economic Growth } \\
\text { in 2017 (\%) }\end{array}$ & \multicolumn{1}{c}{ Social Crisis Background } \\
\hline 1. & Chad & -2.953 & $\begin{array}{l}\text { Political and religious conflict: radical rebellion } \\
\text { Political and religious conflicts: the rebellion of the } \\
\text { radical Islamic State of Iraq and Syria (ISIS) }\end{array}$ \\
2. & Iraq & -2.073 & $\begin{array}{l}\text { Political and religious conflicts: a civil war between } \\
\text { the Houthis and pro-government militias }\end{array}$ \\
3. & Yaman & -5.942 & \\
\hline
\end{tabular}

Source: World Bank

By looking at the phenomenon in OIC countries, many researchers and experts are now paying attention to the interaction between the social dimension and economic growth. The discussion of the relationship between the social dimension and economic growth is the latest discussion in the study of "growth factors". In its development, there are four determinants which are believed to influence economic growth, namely physical capital, natural resource capital, human capital, and most recently, social capital.

The study of "growth factors" has long been a quite interesting discussion and continues to grow today. Initially, physical development capital was considered to have an important role in economic growth, as thought by Harrord-Domar and 
Solow. Further developments, human capital (knowledge and skills) began to get attention because of its role in determining the productivity of human resources (Meier \& Stiglitz, 2001). The latest developments, stressing the importance of social capital as a determining factor of economic growth.

The theory that explains the relationship between social capital and economic performance has been explained by some scholars (Olson, 1982; North, 1990; Fukuyama, 1995). Meanwhile, the influence of social capital on economic growth has been investigated by some other scholars (Rupasingha, Goetz, \& Freshwater, 2000; Boulila, Bousrih, \& Trabelsi, 2008). Based on the theory and research findings, social capital influences economic growth through its role in reducing transaction costs associated with the economic exchange and creating productivity.

Forms of social capital that is supposed to influence the economic growth of the OIC countries is religious tolerance, political participation, and marriage. Religious tolerance plays a role in overcoming the negative impact of terrorism on the economy. Meanwhile, political participation plays a role in overseeing government policies that can harm the economy. Marriage plays a role in overcoming the negative impact of low-quality human resources on the economy.

However, the OIC countries also face some issues of social capital which are thought to have a negative impact on the economy, such as a corruption culture and discrimination behavior. Corruption causes the composition of government expenditure to be less productive, and thus affects economic growth. Discrimination behavior causes weak social cohesion that exists between communities, so the intensity of information exchange will decrease, and transaction costs will increase which affect economic growth.

Development programs that take account of social capital such as religious tolerance, political participation, marriage, corruption culture, and discrimination behavior are needed considering the OIC makes the issue of terrorism, institutional reform and human development as the agenda points in the OIC - 2025 Program Action. However, if viewed from the planned implementation of the OIC -2025 Program Action, there are not many programs that include elements of social capital. Therefore, this study tries to provide an overview of the role of social capital in religious tolerance, political participation, marriage, corruption culture, and discrimination behavior towards the economy.

\section{Literature Review}

Social capital is a set of informal norms or values that are shared by members of a group that enables cooperation between them (Fukuyama, 1995). Fukuyama 
explained that social capital has the power to influence the principles underlying the economic progress of a country. Fukuyama found evidence that countries that have high trust societies tend to have more established economic progress. Conversely, countries with low trust societies tend to have slower economic progress.

In a similar vein, Putnam emphasised social capital on civic involvement, participation in voluntary associations, along with activities such as voting (Rupasingha et al., 2000). Civil involvement promotes trust-building and cooperation through repeated interactions so as to reduce transaction costs during economic exchanges.

Social capital provides two main contributions to development, through economic and political functions. The economic function of social capital is a tool to reduce transaction and information costs. When transaction costs, collection and distribution information costs are reduced, less risk is involved, and more exchanges occur, thus enlarging the scope of transactions and interactions (Rupasingha et al., 2000). Furthermore, social capital also has an important influence on the distribution of household income and poverty (Malik, 2014). Meanwhile, the political function of social capital works in the dynamics of civil society where there is mutual trust between citizens, and between citizens and the state.

Rupasingha et al. (2000) found that economic growth is influenced by social capital. They analyzed the impact of social capital on the economic growth rate of districts in the United States. Social capital is proxied by (i) association activities, (ii) crime index, (iii) charity activities, and (iv) voting. This research uses quantitative methods and is analyzed using linear regression. The results of this study are: first, association activities have a statistically significant positive effect on economic growth. Second, crime has a significant negative effect, indicating that high crime rates in a region have a negative impact on economic growth. Third, charity has a positive effect on economic growth. Fourth, voting has a positive effect but then decreases.

Ertimi et al. (2016) analyzed the relationship between corruption and the economic growth rate in 14 OIC countries. This research uses quantitative methods and is analyzed using panel data regression. The results of the research estimation show that corruption measured using the Economic Freedom Index (EFI) has a negative effect on the economic growth rate.

Boulila et al. (2008) formulated mathematical equations related to social capital and economic growth. In his research, a model was constructed, which explained how the explanatory variables consisting of trust levels in a country (Trust), and transmission channels variables (TC) affected economic growth. The mathematical explanation is as follows. 
The growth equation is:

$\mathrm{G}^{\mathrm{i}} \mathrm{Y}=\alpha 0+\alpha 1 \ln \left(Y^{\mathrm{i}} 0\right)+\alpha 2$ Trust $^{\mathrm{i}}+\alpha 3 \mathrm{TC}^{\mathrm{i}}+\varepsilon^{\mathrm{i}}$

The transmission channels equation:

$T C^{i}=\beta 0+\beta 1 \ln \left(Y^{i} 0\right)+\beta 2$ Trust $^{\mathrm{i}}+u^{\mathrm{i}}$

The substitution of equation (2.2) into equation (2.1) gives:

$\mathrm{G}^{\mathrm{i}} \mathrm{Y}=(\alpha 0+\alpha 3 \beta 0)+(\alpha 1+\alpha 3 \beta 1) \ln \left(Y^{\mathrm{i}} 0\right)+(\alpha 2+\alpha 3 \beta 2)$ Trust $^{\mathrm{i}}+\left(\alpha 3 \mathrm{u}^{\mathrm{i}}+\varepsilon^{\mathrm{i}}\right)$

\section{Methods}

As explained above, this study uses panel data analysis techniques. Data is collected from the Social Progress Index and the GDP Growth Report published by Social Progress Imperative and the World Bank. Considering the availability of data, this study uses data for the annual periods of 2014-2017.

Panel data analysis techniques have advantages over other analysis techniques because panel data analysis techniques accommodate differences in characteristics between individuals and time. The equation of the regression model used in the study:

GDPGRit $=\beta 1 i+\beta 2$ FRlit $+\beta 3$ PRIit $+\beta 4$ PMWit $+\beta 5$ CPIit $+\beta 6$ DVlit $+\varepsilon i t$ Where:

GDPGR : Gross Domestic Product Growth Rate

FRI : Freedom of Religion Index

PRI : Political Rights Index

PMW : Percentage of Married Woman

CPI : Corruption Perception Index

DVI : Discrimination and Violence Against Minorities Index

The selection of the best model panel data regression can be made through the chow test, Haussmann test, and Lagrange multiplier test. Before being able to estimate panel data, a test instrument is first performed through the unit root test. After that, to find out whether the model we built is fit or not, a classic assumption test is also done.

\section{Results and Discussion}

Table 2 displays the results of the unit root test using the Phillips-Peron Test. The test results show that all research variable data are stationary at the level except the marriage variable. Marriage variables are classified into variables which generally 
do not follow the movement of a particular trend because it is data obtained from questions in the form of choice (married or not married), so there is no fear of stationary problems.

Table 2. The Results of Stationarity Test

\begin{tabular}{lcc}
\hline \multicolumn{1}{c}{ Variable } & Probability & Decision \\
\hline Economic Growth & 0.0000 & Stationer \\
Freedom of Religion Index & 0.0000 & Stationer \\
Political Rights Index & 0.0113 & Stationer \\
Percentage of Married Woman & 1.0000 & Non-stationer \\
Corruption Perception Index & 0.0008 & Stationer \\
Discrimination Against Minorities Index & 0.0107 & Stationer \\
\hline
\end{tabular}

Source: Estimated Result

After getting the conclusion that all data is stationary at the level, our model does not require further testing to find out whether there is a long-term balance between the variables of economic growth and selected social capital.

Table 3 displays the results of the Chow Test, Hausman Test, and Lagrange Multiplier Test to determine the best model between common effect (CEM), random effect (REM), and fixed effect (FEM):

Table 3. The Results of Chow Test, Hausman Test, and LM Test

\begin{tabular}{lcccc}
\hline Model $^{*}$ & Model & Prob. & Hasil & Decision \\
\hline $\begin{array}{l}\text { Predictors: freedom of religion } \\
\text { index (FRI), political rights index }\end{array}$ & Chow & 0.0000 & Fixed Effect & \\
$\begin{array}{l}\text { (PRI), percentage of a married } \\
\text { woman (PMW), corruption }\end{array}$ & Hausman & 0.0140 & Fixed Effect & Fixed \\
$\begin{array}{l}\text { perception index (CPI), and } \\
\text { discrimination and violence against } \\
\text { minorities index (DVI) }\end{array}$ & $\begin{array}{c}\text { Lagrange Multiplier } \\
\text { (CEM : REM) }\end{array}$ & 0.0099 & $\begin{array}{c}\text { Random } \\
\text { Effect }\end{array}$ & \\
\hline
\end{tabular}

Source: Estimated Result

${ }^{*}$ GDP Growth (GDPGR) as the dependent variable

Based on table 3 above, it can be decided that the fixed effect model (FEM) is better than the common effect (CEM) and the random effect (REM) model. This is because the probability value is smaller than 0.05 which makes the Hausman test prefer the fixed effect (FEM) model. 
Multicollinearity test aims to detect whether, in the model, there is a correlation relationship between independent variables. Multicollinearity test can be seen from the correlation value between independent variables as follows:

Table 4. Multicollinearity Test

\begin{tabular}{cccccc}
\hline Model $^{*}$ & FRI & PRI & PMW & CPI & DVI \\
\hline FRI & 1.000000 & 0.564421 & 0.438418 & 0.058032 & -0.316389 \\
PRI & 0.564421 & 1.000000 & 0.261732 & 0.190834 & -0.099171 \\
PMW & 0.438418 & 0.261732 & 1.000000 & -0.181688 & 0.062472 \\
CPI & 0.058032 & 0.190834 & -0.181688 & 1.000000 & -0.463869 \\
DVI & -0.316389 & -0.099171 & 0.062472 & -0.463869 & 1.000000 \\
\hline
\end{tabular}

Source: Estimated Result

*GDP Growth (GDPGR) as the dependent variable

The overall value of the correlation coefficient shows a value of $<0.85$, where the value of $<0.85$ indicates that there is no multicollinearity between independent variables.

The Heteroscedasticity test aims to detect whether, in the model, there has been a constant error variance. The Heteroscedasticity test in this study was carried out by the Glejser Test. The output of the Glejser Test estimation results is as follows:

Table 5. Heteroscedasticity test

\begin{tabular}{cccc}
\hline Model $^{*}$ & Prob. & The position to the $\boldsymbol{\alpha}=\mathbf{0 : 0 5}$ & Decision \\
\hline FRI & 0.9510 & Greater than & \\
PRI & 0.3663 & Greater than & No heteroscedasticity \\
PMW & 0.9373 & Greater than & \\
CPI & 0.4236 & Greater than & \\
DVI & 0.8735 & Greater than & \\
\hline
\end{tabular}

Source: Estimated Result

* Residual absolut (RESABS) as the dependent variable

Decision making for the Glejser Test is as follows:

1. If the independent variable $\mathrm{p}$-value is $<0.05$, then there is the problem of heteroscedasticity.

2. If the independent variable p-value is $>0.05$, there is no problem with heteroscedasticity. 
The results of the p-value for all independent variables are greater than 0.05 . Thus there is no problem of heteroscedasticity.

Autocorrelation test aims to detect whether, in the model, there has been a residual correlation between the observation units. The autocorrelation test in this study was carried out by the Durbin-Watson (DW) test. Decision making is done by comparing the Durbin Watson statistic value (d) with the upper bound or du Durbin Watson value and the lower bound (lower bound or $\mathrm{dl}$ ) in the table. The Durbin-Watson statistical value (d), upper bound (du) Durbin-Watson, and lower bound Durbin-Watson $(\mathrm{dl})$ are shown in Table 6 below:

Table 6. Autocorrelation Test

\begin{tabular}{cccccc}
\hline & dl & du & d & 4-du & 4-dl \\
\hline Nilai & 1.7107 & 1.8174 & 2.217774 & 2.1826 & 2.2893 \\
\hline
\end{tabular}

Source: Estimated Result

The values of $\mathrm{dw}, \mathrm{dl}$, and du if positioned based on the strong-weak category of autocorrelation are as follows:

Figure 1. Autocorrelation Category

\begin{tabular}{|l|l|l|l|l||l|l|l|}
\hline $\begin{array}{c}\text { Positive } \\
\text { Autocorrelation }\end{array}$ & \multicolumn{2}{|c|}{ Doubtful } & \multicolumn{2}{|c|}{ No autocorrelation } & \multicolumn{2}{|c|}{ Doubtful } & \multicolumn{1}{c|}{$\begin{array}{c}\text { Negative } \\
\text { Autocorrelation }\end{array}$} \\
\hline & $\mathrm{dl}$ & $\mathrm{du}$ & 4-du & $\mathbf{d w}$ & 4-dl & \\
\hline 0 & & & & & \\
\hline
\end{tabular}

Because the value of $d w 2.21$ is greater than the upper limit (du) 1.81, it can be concluded that there is no positive autocorrelation in the regression model.

Table 7. The Empirical Results

\begin{tabular}{lcccc}
\hline \multicolumn{1}{c}{ Variable } & Coefficient & Std. Error & t-Statistic & Prob. \\
\hline Freedom of Religion Index & 5.846947 & 2.572948 & 2.272470 & 0.0246 \\
Political Rights Index & -0.585801 & 0.170833 & -3.429094 & 0.0008 \\
Percentage of Married Woman & 0.171087 & 0.286453 & 0.597262 & 0.5513 \\
Corruption Perception Index & -0.044628 & 0.166959 & -0.267298 & 0.7896 \\
Discrimination Index & -0.176944 & 1.414382 & -0.125103 & 0.9006 \\
\hline
\end{tabular}




\begin{tabular}{ll}
\hline R-squared & 0.452005 \\
Adjusted R-squared & 0.246999 \\
F-statistic & 2.204843 \\
Prob(F-statistic) & 0.000137 \\
\hline
\end{tabular}

Source: Estimated Result

Table 7 displays the results of panel data regression estimation in the form of the value of the influence of independent variables on the dependent variable.

Based on Table 7, the R-squares value is 0.452005 . The value of 0.452005 indicates that the independent variable is able to explain $45 \%$ of the variation of the dependent variable, and $55 \%$ is explained by other variables outside the model. Estimated models obtained are:

$$
\begin{aligned}
\text { GDPGRit }= & -3.417857 \mathrm{i}+5.846947 \text { FRIit }-0.585801 \text { PRIit }+0.171087 \text { PMWit } \\
& -0.044628 \text { CPIit }-0.176944 \text { DVIit }+ \text { uit }
\end{aligned}
$$

This means that the estimated economic growth reaches $-3.417857 \%$, which is not influenced by the high and low level of religious freedom (FRI), political participation (PRI), marriage (PMW), corruption (CPI), and discrimination (DVI), but influenced by other variables which is not in the model (other variables that are outside the model).

The results of the study on the influence of constructive social capital variables on economic growth can be explained as follows:

First, the religious tolerance variable (FRI) shows a significance value of $0.0246(\mathrm{p}<0.05)$ which means that it has a significant effect on economic growth. The regression coefficient value of religious tolerance variables (FRI) is 5.846947, which means that when the religious freedom index increases by 1 scale, economic growth will increase by $5.846947 \%$ or vice versa. These results accept the hypothesis formulated in the study that religious tolerance has a positive effect on economic growth. This indicates that tolerant religious life will increase cooperation and performance so that productivity increases and contributes to economic growth.

Second, the political participation variable (PRI) shows a significance value of 0.0008 ( $\mathrm{p}<0.05$ ) which means that it has a significant effect on economic growth. The regression coefficient value of political participation variable (PRI) is equal to -0.585801 , which means that when the index of political participation increases by 1 scale, economic growth will decrease by $0.585801 \%$ or vice versa. These results reject the hypothesis formulated in the study that political participation has a positive effect on economic growth. This is consistent with the findings of 
Rupasingha, Goetz, and Freshwater (2000), which state that political participation influences the decline in economic growth.

When political participation increases, the intensity of conflicts between groups also increases. The ability of the state to deal with conflict when political participation increased will determine economic conditions. When a country is unable to handle the conflict, it is considered as a form of negative sentiment that can affect the stock market's fall. As a result, there has been a decline in investor interest to invest, and in the end, the economy will be sluggish, and this will give an impact on slowing economic growth.

Political participation can be both institutional and non-institutional. Voting in elections, conducting political meetings, and joining parties are institutional political participation. Meanwhile, non-institutional political participation can be done by giving petitions, boycotts and demonstrations. Noninstitutional political participation is the most intense form of participation in the government legislature, by voicing demands that the legislature can make a policy that is able to accommodate the voices of the people. The policy that was finally put in place by the government to accommodate the aspirations of the people in this non-institutional form often did not consider the long-term impacts, such as the stability of the economy. The demands of a labor wage increase are an example, where the profits obtained by workers from salary increases can actually have a detrimental effect on the economy. The increase in wages causes the cost of production of the company to increase, which results in an increase in the prices of goods in the market, which is one of the causes of inflation so that the economy will be disrupted.

Third, the marriage variable (PMW) shows a significance value of 0.5513 ( $>$ > 0.05) which means that it has no significant effect on economic growth. The marriage variable (PMW) regression coefficient is 0.171087 , which means that when the percentage of married women increases by $1 \%$, economic growth will increase by $0.171087 \%$ or vice versa. These results accept the hypothesis formulated in the study that marriage has a positive effect on economic growth. But the marriage variable is not a variable that significantly affects economic growth during the observation period.

The results of the study on the effect of destructive social capital variables on economic growth can be explained as follows:

First, the corruption culture variable shows a significant value of 0.7896 ( $p>0.05$ ) which means that it has no significant effect on economic growth. The regression coefficient value of the culture corruption variable (CPI) is -0.044628 , 
which means that when the corruption perception index increases by 1 scale, economic growth will decrease by $0.044628 \%$ or vice versa. The corruption perception index has a scale range of $0-100$, where the number approaches 100 means that corruption is getting cleaner and the number close to 0 means that corruption is getting higher, so the meaning of negative regression coefficient in this study is that corruption is positively related to economic growth. This result rejects the hypothesis formulated in the study that corruption is negatively related to economic growth. This is different from the findings of Ertimi et al. (2016) which states that corruption affects the decline in economic growth. But the corruption variable is not a variable that significantly influences economic growth during the observation period.

Second, the discrimination variable shows a significance value of 0.9006 ( $p>0.05$ ) which means that it has no significant effect on economic growth. The regression coefficient of discrimination (DVI) variable is -0.176944 , which means that when the discrimination and violence against minorities index increase by 1 scale, economic growth will decrease by 0.176944 or vice versa. These results accept the hypothesis formulated in the study that discrimination has a negative effect on economic growth. But the discrimination variable is not a variable that significantly influences economic growth during the observation period.

\section{Conclusion}

This study has analysed the relationship between social capital and economic growth among OIC countries measured using 5 (five) proxies, namely: religious tolerance (FRI), political participation (PRI), marriage (PMW), corruption culture (CPI), and discrimination behavior (DVI). From the results of the analysis obtained, this study concludes, first, the finding that an increase in religious freedom will promote economic growth. Therefore it is necessary to develop programs to strengthen religious tolerance among citizens. Second, the finding that increased political participation can reduce economic growth implies that the ability of the country to minimize the risk of conflict arising from increased political participation will determine economic conditions. The ability of the country to overcome the risk of conflict when political participation increases affect the investment climate and the Composite Stock Price Index (CSPI) which further influences the condition of economic growth. Therefore the country needs to carry out its functions to maintain security and political stability when political participation increases. 


\section{References}

Boulila, Ghazi, Bousrih Lobna \& Mohamed Trabelsi. 2008. «Social Capital And Economic Growth: Empirical Investigations On The Transmission Channels." International Economic Journal 22(3): 399-417. Retrieved from DOI.ORG/10.1080/10168730802287994

Ertimi, Basem, Abulkasem Dowa, Elham Mohamed Albisht \& Basim Aboubaker Oqab. 2016. "The Impact of Corruption on Economic Growth in OIC Countries." International Journal of Economics and Finance 8(9), 91-103. Retrieved from DOI.ORG/10.5539/IJEF.V8N9P91

Fukuyama, F. (1995). Trust: The Social Virtues and The Creation of Prosperity. New York: The Free Press.

Malik, Maszlee. 2014. "Islahi Social Capital : A Conceptual Approach Towards Faith-Based Development and Poverty Alleviation." Kyoto Bulletin of Islamic Area Studies 7(March): 33-48.

Meier, Gerald M, \& Stiglitz Joseph E. 2001. Frontiers of Development Economics: The Future in Perspective. New York: Oxford University Press, Inc.

North, D., 1990. Institutions, Institutional Change, and Economic Performance. New York: Cambridge University Press.

Olson, Mancur. 1982. The Rise and Decline of Nations: Economic Growth, Stagflation, and Social Rigidities. New Haven, CT: Yale University Press.

Rupasingha, Anil, Stephan J Goetz \& David Freshwater. 2000. "Social Capital and Economic Growth : A County-Level Analysis.” Journal of Agricultural and Applied Economics 32(3): 565-572.

Sab, Randa. 2014. "Economic Impact of Selected Conflicts in the Middle East: What Can We Learn from the Past ?" IMF Working Paper: 1-31

SESRIC. 2016. State of Gender in OIC Countries: Prospects and Challenges. Ankara: Statistical, Economic and Social Research and Training Centre for Islamic Countries (SESRIC).

Uddin, Md Akhter \& Mansur Masih. 2016. War and peace: why is political stability pivotal for economic growth of OIC countries? MPRA (71678). Retrieved from https://mpra.ub.uni-muenchen.de/71678/

UNDP. 2016. Organization of Islamic Cooperation (OIC): Statistical Briefing Based on the 2016 Human Development Report. New York. 